DOI https://doi.org/10.30929/2307-9770.2021.09.03.03

UDC 37.01/.09:811/339.9+057 (045)

\title{
Modern Regularities and Principles of Foreign Language Education of Future Specialists in International Relations in the Process of Professional Training
}

\author{
Vasylyshyna N.*
}

National Aviation University, Kyiv, Ukraine

\author{
Received: $09.09 .2021 \quad$ Accepted: 27.09 .2021
}

\begin{abstract}
The relevance of this study is that in Ukraine, foreign language education acquires a special status, which is argued by the fact that language creates an effective basis for international and intercultural understanding. However, the problem of implementing intercultural foreign language education in higher education institutions needs further comprehensive analysis and solution. This is evidenced by the analysis of the state of intercultural foreign language education in the works of national and foreign scholars, which demonstrated the numerous views and scientific achievements on the successful implementation of foreign language education in Ukraine. The study of foreign languages in higher education institutions of Ukraine is an indisputable positive feature of curricula, based on the recognition that the study of languages along with significant practical, educational, educational and developmental potential is a necessary condition for the education of modern specialists in international relations. On the other hand, today it is an urgent need in terms of the chosen socio-economic vector of development of our state, as the implementation of the concept of "learning languages during life" is impossible without careful study of languages by future experts in international relations. The study allows us to identify the leading patterns and principles of foreign language education in the European Higher Education Area. In the course of the research it was found out that foreign language education of specialists in international relations is based on regularities and general didactic principles that reflect the main approaches to the organization of education, namely: developmental and educational nature of education; scientificity; regularity and consistency; accessibility; connection of theory with practice; individualization. The research concluded that an open European educational space highlights significant prospects, while requiring efforts to remove barriers and upgrade foreign language teaching and learning systems in higher education. The formation of a single European cultural and economic space actualizes the creation of parameters of "europeanness" of modern Ukrainian science, culture and education.
\end{abstract}

Key words: foreign language education, patterns, principles, training, specialists in international relations.

\section{Сучасні закономірності та принципи іншомовної освіти майбутніх фахівців з міжнародних відносин у процесі фахової підготовки}

\section{Василишина Н. М.}

Національний авіаційний університет, Київ, Україна

\begin{abstract}
Анотація. Актуальність даного дослідження полягає у тому, що в Україні іншомовна освіта набуває особливого статусу, яка аргументується тим, що через мову створюється ефективна основа для міжнародного та міжкультурного взаєморозуміння. Втім проблема реалізації міжкультурної іншомовної освіти у закладах вищої освіти потребує подальшого всебічного аналізу і вирішення. Про це свідчить аналіз стану міжкультурної іншомовної освіти у працях вітчизняних та зарубіжних науковців, який продемонстрував численні погляди та наукові надбання щодо успішної реалізації іншомовної освіти в Україні. Вивчення іноземних мов у закладах вищої освіти України є безперечною позитивною ознакою навчальних планів і програм, виходячи з визнання, що вивчення мов поряд із значним практичним, освітнім, виховним та розвивальним потенціалом $\epsilon$ необхідною умовою освіти сучасного фахівця з міжнародних відносин. 3 іншого боку, сьогодні це $є$ нагальною потребою й з точки зору обраного соціально-економічного вектору розвитку нашої держави, оскільки реалізація концепції «вивчення мов протягом життя» неможлива без ретельного вивчення мов майбутніми
\end{abstract}

Corresponding Author: Vasylyshyna Nataliia Maksymivna, E-mail: filologyN@gmail.com National aviation university, Metrologichna Street 6, flat 103, Kyiv, Ukraine, 03143.

Biдnовідальний автор: Василишина Наталія Максимівна, E-mail: filologyN@gmail.com

Національний авіаційний університет, вул. Метрологічна 6, кв.103, Київ, 03143. 
фахівцями міжнародних відносин. Проведене дослідження дозволяє визначити провідні закономірності та принципи іншомовної освіти в європейському просторі вищої освіти. У ході дослідження було з'ясовано, що іншомовна освіта фахівців міжнародних відносин будується на закономірностях та загальнодидактичних принципах, що відображають основні підходи до організації навчання, а саме: розвивального і виховного характеру навчання; науковості; систематичності та послідовності; доступності; зв'язку теорії з практикою; індивідуалізації. У межах дослідження було зроблено висновок, що відкритий європейський простір освіти висвітлює значні перспективи, водночас вимагаючи докладання зусиль щодо усунення бар'єрів і оновлення систем викладання й навчання іноземних мов у закладах вищої освіти. Формування єдиного європейського культурно-економічного простору актуалізує створення параметрів «європейськості» сучасної української науки, культури й освіти.

Ключові слова: іншомовна освіта, закономірності, принципи, професійна підготовка, фахівці міжнародних відносин.

\title{
Современные закономерности и принципы иноязычного образования будущих специалистов по международным отношениям в процессе профессиональной подготовки
}

\author{
Василишина Н. М. \\ Национальный авиационный университет, Київ, Украина
}

\begin{abstract}
Аннотация. Актуальность данного исследования заключается в том, что в Украине иноязычная образование приобретает особый статус, который аргументируется тем, что через язык создается эффеективная основа для международного и межкультурного взаимопонимания. Впрочем проблема реализации межкультурной иноязычного образования в учреждениях высшего образования требует дальнейшего всестороннего анализа и решения. Об этом свидетельствует анализ межкультурной иноязычного образования в трудах отечественных и зарубежных ученых, который продемонстрировал многочисленные взгляды и научные достижения по успешной реализации иноязычного образования в Украине. Изучение иностранных языков в учреждениях высшего образования Украины является несомненным положительным признаком учебных планов и программ, исходя из признания, что изучение языков наряду со значительным практическим, образовательным, воспитательным и развивающим потенциалом является необходимым условием образования современного специалиста по международным отношениям. С другой стороны, сегодня это является насущной необходимостью и с точки зрения избранное социально-экономического вектора развития нашего государства, поскольку реализация концепции «изучение языков в течение жизни» невозможна без тщательного изучения языков будущими специалистами международных отношений. Проведенное исследование позволяет определить ведущие закономерности и принципы иноязычного образования в европейском пространстве высшего образования. В ходе исследования было выяснено, что иноязычная образование специалистов международных отношений строится на закономерностях и общедидактических принципах, отражающих основные подходы к организации обучения, а именно: развивающего и воспитательного характера обучения; научности; систематичности и последовательности; доступности; связи теории с практикой; индивидуализации. В рамках исследования был сделан вывод, что открытый европейское пространство образования освещает значительные перспективы, одновременно требуя приложения усилий по устранению барьеров и обновление систем преподавания и обучения иностранным языкам в учреждениях высшего образования. Формирования единого европейского культурноэкономического пространства актуализирует создание параметров «европейскости» современной украинской науки, культуры и образования..
\end{abstract}

Ключевые слова: иноязычная образование, закономерности, принципы, профессиональная подготовка, специалисты международных отношений.

\section{Bcmyn}

Протягом останніх п'ятнадцяти років процес стрімкої глобалізації значною мірою трансфрормує національну систему вищої освіти. Саме тому, досить важливо з'ясувати актуальність тенденції стрімкого розвитку вищої освіти врахувавши умови глобалізації культури, а також виокремити її наслідки, спробувати розмежувати твердження глобалізації й інтеграції стосовно освітянського простору. Іншомовна освіти майбутніх фахівців з міжнародних відносин має орієнтуватися передусім на Національну стратегію розвитку освіти в Україні на 2012-2021 роки, у якій освіта проголошується стратегічним ресурсом «соціально-економічного, культурного і духовного розвитку суспільства, 
поліпшення добробуту людей, забезпечення національних інтересів, зміцнення міжнародного авторитету й формування позитивного іміджу нашої держави, створення умов для самореалізації кожної особистості». Курс на виховання людини інноваційного типу мислення і культури через створення акмеологічного освітнього простору з урахуванням освітніх інновацій, запитів особистості, суспільних і державних потреб визнається цим документом як стрижневий [4; 5].

Проведене вивчення дозволяє визначити такі провідні підстави реалізації іншомовної освіти в європейському просторі вищої освіти: економічні й політичні чинники (глобалізація світового устрою та економічна й політична інтеграція в Європі); докладання зусиль на індивідуальному, національному та наднаціональному рівнях для розв'язання проблеми провідними європейськими інституціями (пошук рішень в особистісному й соціолінгвістичному вимірах); фактично узгоджене визначення спільних орієнтирів і практичних рішень щодо розвитку сфери. У контексті вищої освіти визначено план пріоритетних дій: створення відкритого освітнього простору; урахування економічних пріоритетів при визначенні освітніх цілей; акцентування освітнього й розвивального потенціалу вивчення мов і соціальних комунікативних умінь для налагодження ефективного спілкування; подолання негативних проявів; прагнення уникнення міжетнічних конфліктів і непорозумінь; розробка можливих моделей забезпечення іншомовної освіти молоді у закладах вищої освіти [8].

Питанням мовної політики, висвітленню кроків із створення європейського простору вищої освіти, входження української освіти до європейського простору, шляхів реалізації першочергових завдань в освіті, у мовній освіті в європейському вимірі зокрема присвячено значну кількість наукових публікацій. Серед них праці В. Андрущенка, В. Бондаря, В. Гаманюк, М. Згуровського, О. Коваленко, Т. Ковальової, В. Кременя, В. Лугового, В. Махінова, С. Ніколаєнка, Л. Ороховської, Н. Пелагеши, С. Саєнко, М. Степка, М. Тадеєвої, Ю. Чередник, О. Яковлєвої та інших науковців. Утім їх актуальність фокусує на подальше вивчення та випрацювання конкретних орієнтирів і настанов щодо організації, змісту, методів, форм навчання мов, досягнення конкретних рівнів їх володіння на певних рівнях інституційної освіти, реального забезпечення реалізації стратегії вивчення мов упродовж життя.

Mema cmammi - розглянути сучасні принципи, закономірності розвитку питань іншомовної освіти майбутніх фахівців міжнародних відносин в межах інтегрування Європейського простору вищої освіти.

\section{II Матеріал і методи дослідження}

На вищі навчальні заклади покладено основне завдання - адаптація до вимог глобалізаційної епохи. Варто підкреслити, що сучасний, конкурентоспроможний університет повинен постійно враховувати сучасні зміни суспільства стосовно культурного та наукового технічного розвитку, задля того, щоб мати можливість знайти себе в реаліях сьогодення.

I.B. Бурачек вважає, що безперервним процесом функціонування системи вищої освіти $є$ їі постійне ускладнення відносин глобалізованого та високо-інформаційного суспільства, що зазвичай беруть ототожнювати з поняттями, такими як: інтернаціоналізація та глобалізація. Розглядаючи дану проблему, освітня інтернаціоналізація створює вільним процес обміну викладачами та студентами 3 різних країн світу, а також створює єдині спеціальні навчальні програми [9].

Аналіз зарубіжних педагогічних джерел показує, що питання іншомовної освіти займають чільне місце у наукових дослідженнях американських науковців. Термінологічний апарат педагогіки в контексті іншомовної освіти розвивають Дж. Кнайт, Б. Сільвестер, Дж. Харлей, П. Россело, Г. Каролл, Г. Де Віта і П. Касс, Дж. Беккер, Дж. Трондал, П. Скотт, Дж. Стієр, А. Мореу, Р. Рунт, С. Ледвіс і Д. Сеймоур, М. Крішнамерті та ін. М. Теодор і В. Брікман досліджують історію іншомовної освіти. Тенденції розвитку цієї освіти відображені у роботах В. Стеварта і Ш. Кагана. Міжнародна освіта як складова сучасної глобалізації актуалізується А. Кеннесом і Д. Тайа. Вивченню змін напрямів розвитку міжнародної освіти присвятив свої праці С. Джіллеспі [2; 3; 9].

Огляд інформаційних джерел свідчить про достатню розробленість проблеми професійної підготовки фахівців в сучасній науковій літературі. Автори низки наукових розвідок провели ґрунтовний аналіз досліджень і публікацій з цієї тематики, виокремивши різні підходи до визначення поняття «професійна підготовка» (Бірюкова Л. А., Глазкова І. Я., Демешкант Н. А., Кулешова В. В., Поліщук Л. П., Томащук О. Г., Адаму А. Й. (Adamu А. Ү.), Белло М. І. (Bello M. І.), Данжума І. M. (Danjuma I. M.), Муді Г. (Moodie G.) [8; 9]. 


\section{III Результати}

Перша закономірність ґрунтується на розумінні іншомовної освіти як суспільного й індивідуальноособистісного явища, яке розглядається з позиції його внутрішньої сутності, пов'язаної з формуванням суспільної та індивідуальної свідомості, та $є$ ї̈ духовною складовою, зумовленою гуманістичними вимогами суспільного розвитку. Вона пов'язана з необхідністю формування комунікативної культури магістрів сорери туризму, визначеною модернізацією та інтеграцією вітчизняної системи освіти в європейський і світовий освітній простір, загостренням конкуренції на ринку праці та підвищенням вимог сфери послуг до професійної культури випускників.

Відповідно до другої закономірності, конкурентоздатність фрахівця сфери туризму визначається рівнем розвитку його іншомовної освіти в її особистісному та професійному значенні. 3 цих позицій іншомовної освіти є вагомим показником загальної та професійної культури фахівця, а її формування пріоритетним напрямом його особистісного розвитку та професійного становлення у професійній підготовці.

Третя закономірність полягає в тому, що процес іншомовної освіти належить до пізнавальноперетворювальної діяльності, яка $є$ результатом педагогічного впливу, ґрунтується на певних якостях особистості, спрямована на забезпечення її саморозвитку на аксіологічних і гуманістичних засадах. Це означає його залежність від зовнішніх і внутрішніх умов [2; 3].

У четвертій закономірності відображається цілеспрямованість розвитку іншомовної освіти фахівців міжнародних відносинах його цілісної професійно-особистісної характеристики, вираженої в єдності особистісно-рефрлексивного, гносеологічно-когнітивного, операційно-технологічного і професійно-адаптивного компонентів. Це означає, що працівник сфери туризму має бути самостійним, інтелектуально-розвинутим, здатним розуміти мотиви своїх вчинків і відповідати за їх наслідки, аналізувати процес міжкультурної комунікативної взаємодії у професійній сфрері та прогнозувати його результати, приймати рішення, адекватні комунікативній ситуації й досягати взаєморозуміння 3 партнером по спілкуванню.

Визначені закономірності $€$ теоретичною основою принципів навчання. Проблематика нашого дослідження вимагає застосування загальнодидактичних принципів, спільних для організації навчального процесу в усіх закладах освіти, принципів професійного навчання і специфрічних принципів з метою забезпечення ефективності процесу набуття іншомовної освіти.

Іншомовна освіта фахівців міжнародних відносин будується на загальнодидактичних принципах, що відображають основні підходи до організації навчання, а саме: розвивального $i$ виховного характеру навчання; науковості; систематичності та послідовності; доступності; зв'язку теорії з практикою; індивідуалізації.

Необхідність принципу розвивального і виховного характеру навчання зумовлюється орієнтацією освіти на розвиток особистісного потенціалу студентів. Він базується на теорії розвивального навчання, розробленій В. В. Давидовим [3], Д. Б. Ельконіним [1] і відображає внутрішні закономірності навчального процесу щодо єдності навчання, виховання, розвитку. Його сутність полягає в актуалізації раніше засвоєних знань і способів дії, висуненні на цій основі гіпотез, пошуків нових ідей щодо вирішення поставленого завдання.

Центральною ланкою тут є самостійна навчально-пізнавальна діяльність, заснована на здатності регулювати свої дії відповідно до усвідомленої мети. Педагогічний вплив ґрунтується на врахуванні його найближчої зони розвитку, внаслідок чого учень не лише засвоює конкретні знання, вміння і навички, а й опановує способи дій, вчиться конструювати і управляти своєю навчальною діяльністю.

У процесі професійної підготовки фахівців міжнародних відносин велике значення, поряд 3 опануванням необхідного обсягу теоретичних знань, формуванням певних професійних навичок і вмінь, має виховання учнів на засадах загальнолюдських, національних і морально-етичних цінностей, які мають стати основою життєвих орієнтирів і соціальної поведінки Інтелектуальний розвиток, професійне становлення і виховання особистості майбутніх кваліфікованих робітників сфери туризму оптимізується у процесі отримання іншомовної освіти, яка сприяє входженню особистості в соціально-професійне середовище, засвоєнню нею суспільного досвіду й морально-етичних норм, установок і цінностей [3; 8; 9]. 
Принцип науковості, за висловом Г. Г. Ващенка, покликаний формувати механізм логічного мислення і любов до наукової правди. В основу розуміння цього принципу видатний педагог радить покладати вимогу щодо відповідності знань об'єктивній дійсності, рівню розвитку суспільних знань, сучасної науки і техніки. Це означає підвищення вимог до змісту навчального процесу і вдосконалення його форм і методів відповідно до сучасних реалій [3].

У профресійному навчанні принцип науковості виявляється передусім у доборі навчального матеріалу і в методах навчання, що застосовуються. Він передбачає не механічне перенесення системи науки в навчальний матеріал туристичної світи, а ії дидактичне і методичне опрацювання, внаслідок якого утворюється нова дидактична система - навчальний предмет. Щодо іншомовної освіти фахівців міжнародних відносин принцип науковості спирається на теорію соціальних комунікацій і виявляється в обгрунтуванні цього процесу за допомогою комплексу загальнонаукових і педагогічних методологічних закономірностей [6; 7].

Принцип систематичності та послідовності в навчанні розглядають як похідний від принципу науковості, оскільки кожна наука, маючи свою систему, передбачає певний порядок і черговість викладу в дидактичному процесі. Цей принцип стосується як змістового, так і процесуального компонентів навчального процесу, тобто визначає його логіку і послідовність. Він відображає загальні закономірності мисленнєвої діяльності в процесі навчання і сприяє розвитку системності мислення шляхом встановлення асоціативних зв'язків між явищами і предметами, що вивчаються. Знання лише тоді будуть дієвими, коли в людини сфрормується чітка картина зовнішнього світу, як система взаємопов'язаних понять [2].

Дієвість принципу систематичності й послідовності в навчанні підсилюється принципом доступності викладання, основна вимога якого стосується організації навчального процесу таким чином, щоб майбутні магістри сфери туризму могли свідомо засвоювати загальнонаукові та професійні знання, виробляти уміння й практичні навички, максимально використовуючи свій потенціал.

Основою принципу зв'язку теорії з практикою є центральне положення класичної філософрії та сучасної гносеології, згідно з яким точка зору життя, практики $є$ першою і основною точкою зору пізнання. Цей принцип спирається на положення філософії, педагогіки і психології про те, що ефективність і якість навчання перевіряються і підтверджуються практикою, яка є критерієм істини, джерелом пізнавальної діяльності та областю застосування результатів навчання [7].

Урахування здібностей учнів, які впливають на їхню навчальну діяльність та її результати, передбачає організація іншомовної освіти за принципом індивідуалізації, заснована на активізації кожного окремо взятого студента відповідно до його індивідуальних особливостей. Завдяки цьому забезпечується цілісний розвиток особистості на основі визнання ії індивідуальності. Водночас, окремі науково-педагогічні джерела акцентують увагу на тому, що цей принцип має передусім привертати увагу до педагогічно цілеспрямованої індивідуалізації навчання. Це означає, що використання будь-яких організаційних фрорм навчання має спрямовуватись на формування професійно-творчих особистісноіндивідуальних якостей фахівців міжнародних відносин[1; 3].

На думку П. І. Сікорського, індивідуальний підхід у професійній освіті передбачає одночасне використання індивідуалізації та диференціації навчання, оскільки індивідуалізація спрямована на врахування специфічних особливостей кожного учня всередині групи, а диференціація передбачає врахування подібних типових особливостей груп студентів [5].

Головною метою профресійної підготовки фахівців міжнародних відносин $€$ фрормування професійних якостей. Зважаючи на це, провідним принципом профредагогіки є принцип професійної спрямованості навчання. Цей принцип виконує функцію стратегічного орієнтира для формування професійно спрямованої особистості [1; 3].

Як зазначають Р. С. Гуревич і А. М. Коломієць, сутність принципу професійно спрямованого навчання полягає у своєрідному використанні педагогічних засобів, коли забезпечується засвоєння учнями передбачених програмами навчальних дисциплін знань, умінь, навичок, досвіду творчої діяльності, та, водночас, успішно формується інтерес до обраної професії, ставлення до неї, професійні якості фахівця [6; 8; 9].

Принцип фундаменталізації є стратегічним напрямом розвитку освіти у XXI ст., сутність якого полягає у перетворенні освіти на фрундамент духовно-моральної та практичної діяльності людей у 
процесі самопізнання, самооцінки та саморозвитку. Фундаментальність освіти передбачає різнобічну гуманітарну і природничу підготовку для формування цілісної картини світу, дозволяє усвідомити закони природи і суспільства, за якими живе людство та які не можна ігнорувати. Як зазначає С. У. Гончаренко, фундаментальність знань фахівців міжнародних відносин має органічно поєднуватися з першокласною професійною підготовкою і високою професійною культурою [127, с. 184]. Серед стратегічних завдань усіх освітніх установ при розробці освіти майбутнього фрахівця ссрери туризму розглядається формування у нового покоління комунікативної культури в складі іншомовної освіти [7; 8].

Принцип технологічності професійної підготовки спрямований на системне застосування науково-педагогічного знання до практичних завдань формування готовності фрахівця до виконання професійних функцій. Він пов'язаний з розглядом навчання як процесу, спрямованого на певний результат і вимагає систематизації знань, умінь і навичок, яка забезпечує послідовне опанування навчально-практичних, загальнопрофесійних і профессійно орієнтованих умінь і навичок, розвиток в майбутніх фахівців міжнародних відносин творчого мислення та самостійності. Технологічний процес професійної підготовки базується на уявленні про технологію як поєднання кваліфікованих навичок i вмінь, засобів, методів, відповідних знань, що необхідні для здійснення бажаних перетворень у суб'єктів навчання [6; 8; 9].

Комунікативна культура іншомовної освіти базується на вмінні орієнтуватися в інфрормаційній структурі суспільства. Соціально-психологічна інформація передається за допомогою мови етикету, використовує стандарти спілкування, коди, знаки, символи. Ї̈̈ інформативний аспект дозволяє розглядати зміст соціально значущої інформації, яка забезпечує стабільність суспільства як систему, що сприяє розумінню та взаємодії людей у процесі спілкування.

У зв'язку зі зростанням швидкості обміну інформацією в усіх сферах життєдіяльності людини, прогресуванням інформаційної складової в діяльності фахівців будь-якого профілю виникла необхідність урахування в їхній професійній підготовці принципу інфоорматизації. А. В. Литвин вважає цей принцип одним із провідних дидактичних принципів профтехосвіти та обґрунтовує його універсальність як такого, що відображає наукове осмислення освітнього процесу, заснованого на використанні можливостей інформаційно-комунікаційних технологій, які $є$ універсальним засобом пізнання. Застосування інфрормаційно-комунікаційних технологій для покращення сприйняття навчального матеріалу сприяє пізнавальній активності та творчому розвитку учнів, за їх допомогою створюються нові методики навчання. Принцип інформатизації дозволяє забезпечити майбутніх фахівців збалансованою системою засобів освіти, самоосвіти і пізнання, що значно підвищує якість підготовки фахівців. Його практична сутність полягає у виробленні необхідних для діяльності в інформаційному суспільстві компетенцій, тобто в тому, щоб навчити майбутніх фахівців працювати 3 інфрормацією [3; 8].

Педагогічна сутність культурологічного підходу відображається в принципі культуровідповідності іншомовної освіти, котрий не суперечить її науковому змісту, а навпаки, доповнює та збагачує його, забезпечуючи таким чином ї̈ справжню гуманізацію та гуманітаризацію. Цей дидактичний принцип обгрунтував Ф. А. Дістервег, наголошуючи, що особистість потрібно формувати відповідно до потреб сучасної їй передової культури та науки [7; 8].

У контексті нашого дослідження принцип культуровідповідності орієнтується на пріоритетні культурологічні ідеї сьогодення, які переходять у зміст, методи й результати навчально-виховного процесу іншомовної освіти і визначають культурологічні основи формування комунікативної культури фрахівців міжнародних відносин.

В основі комунікативної культури лежить загальна культура особистості, яка виражається в системі потреб, соціальних якостей, у стилі діяльності та поведінки. Тому комунікативна культура включає передусім сутнісні особистісні характеристики, а саме - здатності, знання, вміння, навички, установки, особливості характеру [6; 7].

3 огляду на викладене, принцип культуровідповідності набирає особливої ваги і передбачає нерозривний зв'язок процесу просресійної підготовки фрахівців міжнародних відносин з культурними надбаннями людства і свого народу, зокрема в царині духовної та матеріальної культури, взаємозв'язків національної культури із загальнолюдською тощо. У центрі цього процесу знаходиться майбутній 
профресіонал, як активна особистість, здатна до самодетермінації у професійному спілкуванні та взаємодії з іншими людьми, гармонії внутрішньої та зовнішньої культури.

Отже, самореалізація особистості детермінована принципом саморозвитку, який вважається психологічною основою освітніх проектів і програм професійного розвитку особистості. Саморозвиток базується на комунікативній діяльності людини. Його сутність полягає у розвитку в людини здатності става-ти і бути справжнім суб'єктом свого життя, перетворювати власну життєдіяльність на предмет практичного перетворення, здійснювати особистісний вибір на основі самопізнання. Принцип саморозвитку дає змогу зацікавити магістра ссрери туризму в потребі самозмін, мотивуючи його подальше становлення як професіонала, здатного до конструювання та розвитку своєї діяльності [6; 7].

Сутність особистісно-орієнтованого підходу запровадженого у рамки нашого дослідження сконцентрована у принципі суб'єктності, який полягає у визнанні й усвідомленні неповторної індивідуальності магістра сфрери туризму, його самоцінності, розвитку не як колективного суб'єкта, а передусім як індивіда з унікальним суб'єктним досвідом, сукупністю психічних, культурних рис. Такі риси властиві людині, яка вміло використовує суб'єктні якості в діяльності, міжкультурному спілкуванні та взаєминах, постійно збагачується духовно, перетворюючи суб'єктивний досвід на цінне джерело власного розвитку.

Провідним принципом діяльнісного підходу є принцип єдності свідомості та діяльності, який декларує їх приналежність свідомому та діючому суб'єкту. Свідомість і діяльність, перебуваючи в тісному, опосередкованому особистістю, зв'язку, зумовлюють одна одну. Цей зв'язок виявляється в тому, що діяльність впливає на формування свідомості, психічних зв'язків, процесів, властивостей особистості, а вони регулюють ії діяльність та $є$ умовою ії адекватності. 3 огляду на це, іншомовна освіта магістра сфрери туризму потребує високого рівня усвідомленості й творчої активності в міжкультурній комунікативній діяльності [3; 6].

3 цих міркувань провідним принципом компетентнісного підходу іншомовної освіти магістра сфери туризму визначено принцип иілісності, який відображає увесь комплекс завдань, необхідність вирішення яких може виникнути в ході професійній діяльності.

За словами І. А. Зязюна, він спрямований на фрормування «метакомпетентності» - цілісної характеристики фахівця, спроможного вирішувати найрізноманітніші ситуації, які виникають у професійній сфрері. Такою «метакомпетентністю» у професійній діяльності фрахівців міжнародних відносин є їхня професійна комунікативна міжкультурна діяльність, що включає теорію і практику конструктивного вирішення професійно-комунікативних ситуацій, має будуватися на основі аналізу та інтерпретації професійно-комунікативної взаємодії [2].

Отже, концептуальні засади іншомовної освіти фрахівців міжнародних відносин зумовлені загальними педагогічними закономірностями і специфічними закономірностями її набуття та спираються на взаємозв'язок загальнодидактичних принципів, принципів професійної освіти і специффічних принципів формування комунікативної культури.

\section{IV Обговорення}

Студенти немовних спеціальностей мають оволодіти загальновживаною і професійно орієнтованою іноземною мовою. Подолання протиріччя між вимогами суспільства і можливостями сучасної вищої школи у підготовці спеціалістів викликає необхідність пошуку нових методів і засобів навчання майбутніх фахівців. Концепція особистісно орієнтованої освіти передбачає впровадження у навчально-виховний процес інноваційних методів і форм організації навчально-пізнавальної діяльності студентів. Одним із можливих шляхів реалізації особистісно орієнтованого навчання є впровадження у навчально-виховний процес інформаційно-комунікаційних технологій, що $є$ одним із шляхів інтенсифікації навчального процесу в умовах їх комплексного застосування.

Проблему формування іншомовної професійної підготовки у студентів немовних спеціальностей висвітлено у працях А. Астадур'ян, Л. Борозенець, Н. Гавриленко, О. Григоренко, М. Євдокімова, В. Зикова, Е. Комарова, Н. Кучеренко, Т. Лучкіна, Ю. Маслова, О. Метьолкіної, О. Фадєйкіна та ін.; методику формування ІКК досліджували вітчизняні та зарубіжні вченіметодисти, а саме: І. Баценко І. Берман, В. Борщовецька, В. Гнаткевич, О. Ізмайлова, Н. Катрич, Е. Мірошниченко, Ю. Пассов, Ю. Солодовнікова, О. Тарнопольський, В. Теніщева, О. Чиханцова, С. Шатілов, Р. Елліс (R. Ellis), I. Нейшн 
(I. Nation), H. Шмітт (N. Schmitt), В. Віддовсон (W. Widdowson) та ін. Вчені зазначають, що IКК $€$ невід'ємною складовою підготовки студентів немовних спеціальностей, оскільки сприяє продуктивній взаємодії з навколишнім світом, тобто успішному професійному становленню майбутнього фрахівця. Тому перед вищою школою виникла потреба пошуку і впровадження у практику актуальних методів навчання IM, які сприятимуть формуванню іншомовної професійної підготовки у студентів немовних спеціальностей $[7 ; 8]$.

Детальний аналіз вітчизняної і зарубіжної літератури продемонстрував, що плеяда вчених розглядала проблему іншомовної освіти з різних сторін, а саме були описані такі аспекти іншомовної освіти, як: міжкультурної комунікації; іншомовної комунікації; крос-культурний менеджмент; питання теорії туристської освіти; педагогічні фактори підвищення культурної цінності туризму; теоретичні основи професійної підготовки; питання розвитку багаторівневої системи безперервної професійної освіти; проблема впровадження й удосконалення стандартів професійної освіти; питання підвищення якості підготовки фахівців; різні підходи до визначення поняття «професійна підготовка»; теоретичні аспекти становлення та розвитку іншомовної освіти; кваліфікаційно-дидактична структура професійної освіти сфрери міжнародних відносин; наповнення іншомовної освіти та вибору методів; технології, моделі та методики навчання у сфері міжнародних відносин; питання вивчення іноземних мов студентами міжнародних спеціальностей; практичної підготовки студентів немовних вузів; проблема розвитку і трансформації освіти, питання реструктуризації системи професійної підготовки; питання організації професійної підготовки фахівців сфери міжнародних відносин у вищих навчальних закладах України; питання забезпечення сфери міжнародних відносин України кваліфрікованими кадрами.

\section{V Висновки}

Актуальність проблеми іншомовної підготовки студентів міжнародників пов'язана 3 впровадженням загальноєвропейських стандартів підготовки конкурентоздатних фрахівців, що зумовили виділити іншомовну підготовку студентів немовних спеціальностей як складника фахової підготовки випускників університетів. Відповідно до Загальноєвропейських Рекомендацій з мовної освіти щодо рівня володіння іноземною мовою студенти вищих навчальних закладів повинні "володіти уміннями вільно висловлюватись без суттєвої витрати часу на пошук адекватних мовних засобів у процесі досягнення ними соціальних, академічних і професійних цілей".

Іншомовна професійна підготовка міжнародника повинна відповідати вимогам часу, бути зорієнтованою на розширення кола професійних ролей та функцій, перспективу міжнародної співпраці, забезпечувати можливість мобільності як науковців, так і студентів у межах світового освітнього простору. Специфіка іншомовної підготовки студентів закладів вищої освіти повинна відповідати вимогам Загальноєвропейських Рекомендацій з мовної освіти і передбачати дотримання сучасних дидактичних та методичних принципів навчання іноземних мов: інтерактивності, інтеграції, мовленнєвомисленнєвої активності, контекстуалізації, домінуючої ролі безперекладної семантизації, інтернаціоналізму та плюрилінгвізму, варіативності та раннього професійного спрямування в навчанні іноземної мови.

Отже, іншомовна професійна підготовка міжнародника є складним і багатогранним поняттям, що включає в себе як професійні знання в галузі міжнародних відносин, так і професійну мовну підготовку. Цим і пояснюється специфіка професійної підготовки міжнародників, адже необхідно формувати не тільки професійні вміння й навички, а й готовність приймати рішення, брати на себе відповідальність за певні дії, здійснювати професійну діяльність іноземною мовою з урахуванням контекстуальної значущості ситуації, особливостей мовної картини світу країни перебування, лінгвістичних та екстралінгвістичних фракторів, що обумовлюють ведення переговорів.

Таким чином, основна мета іншомовної освіти полягає в підготовці кваліфікованого робітника відповідного рівня, конкурентоспроможного на ринку праці, який вільно орієнтується у професії. Ї̈̈ досягнення потребує визначення цілей та відбору змісту освіти, організації навчального процесу й оцінки його результатів на таких засадах: сутність освіти полягає в розвитку здатності фахівців сфрери туризму самостійно вирішувати проблеми і видах діяльності на основі використання соціального досвіду, елементом якого є і його власний досвід; сенс організації освітнього процесу відображається у створенні умов для формування досвіду самостійного вирішення майбутніми фахівцями пізнавальних, 
комунікативних, організаційних, моральних та інших проблем, що становлять зміст сучасної іншомовної освіти.

\section{Бібліографрічні посилання}

1. Антонюк Н. М. Вивчення іноземних мов в контексті гуманістичної освіти. Вісник Академії адвокатури України. 2009. №1. C. 228-233.

2. Безкоровайна О. В. Актуальні аспекти комунікативної компетенції студентів ВНЗ. Наукові записки [Національного університету "Острозька академія"]. Сер.: Філологічна. 2012. №25. С. 142-145.

3. Ігнатюк О. А. Особливості підготовки сучасних фахівців у системі вищої професіійної освіти США. Теорія і практика управління соціальними системами. 2011. №1. С. 55-64.

4. Іщенко О. Вивчення англійської мови в умовах вступу України у європейський освітній простір. Вісник Львівського університету. 2009. №25. С. 353-357.

5. Ніколаєва Ж. В. Навчання іноземних мов у ВНЗ у контексті Загальноєвропейських Рекомендацій з мовної освіти. Наукові праці. Педагогічні науки. 2004. №29. С. 127-130.

6. Полікарпова Ю. О. Традиції та інновації у викладанні іноземних мов в умовах інтеграції України до світової спільноти. 2004. URL: http://www.academia.edu/2079153/ (дата звернення 10.08.2021).

7. Рудницька Т. Г. Інноваційні методи навчання іноземних мов у вищій школі в контексті гуманістичної спрямованості навчального процесу. Гуманізм та освіта. 2008. URL: http://conf.vntu.edu.ua/humed/2008/txt/Rudnizka.php (дата звернення 10.08.2021).

8. Common European framework of reference for languages: learning, teaching, assessment. Language Policy Unit, Strasbourg. URL: https://www.coe.int/t/dg4/linguistic/Source/Framework_EN.pdf (дата звернення 10.08.2021).

9. Moodie G. Identifying Vocational Education and Training. Journal of Vocational Education and Training. 2002. Vol. 54. № 2. P. $266-289$.

10. Common European framework of reference for languages: learning, teaching, assessment [Електронний ресурс]. Language Policy Unit, Strasbourg. Режим доступу: https://www.coe.int/t/dg4/linguistic/Source/Framework_EN.pdf .

11. Douglas H. Teaching Principles, An Interactive Approach to Language Pedagogy, Third Edition. 2007. P.569. [in English]

12. Harasim L., Hiltz S., Tells L., Turoff M. Learning Networks: a Field Guide to Teaching and Learning on line. Cambridge MA: MIT Press. 1995. 145 p. [in English]

13. Humboldt W. Language and cultural philosophy. M: Progress. 1985. 450 p. [in English]

14. Henning J. The Art of Discussion-Based Teaching: Opening Up Conversation in the Classroom. New York: Routledge. 2008. P. 56 - 78 [in English]

15. Hughes R. Teaching and Researching: Speaking (Applied Linguistics in Action). 2nd ed. Pearson Education Limited. 2011. 197 p. [in English]

16. Littlewood W. Communicative Language Teaching. Cambridge: CUP. 1991. P. 34 - 56.

17. Moodie G. Identifying Vocational Education and Training. Journal of Vocational Education and Training. 2002. Vol. 54. № 2. P. $266-289$.

18. Vasylyshyna N. M. English in Context. K.: PRINT LINE, 2014. 196 p.

19. Yildirim A. A Qualitative Assessment of the Curriculum Development Process at Secondary Vocational Schools in Turkey. Journal of Career and Technical Education. 2001. №1. C. 57 - 59.

20. Zagonari, E. (2009). Balancing tourism education and training: International Journal of Hospitality Management. International Journal of Hospitality Management. №28. C. 2 - 9.

\section{References}

1. Antonyuk, N. M. (2009). Vivchennya inozemnix mov v konteksti gumanistichnoï osviti. Visnik Akademiï advokaturi Ukraïni, №1, C. 228-233. [in Ukrainian]

2. Bezkorovajna, O.V. (2012). Aktual'ni aspekti komunikativnoï kompetencziï studentiv VNZ. Naukovi zapiski [Naczional'nogo universitetu "Ostroz'ka akademiya"]. Ser.: Filologichna, 25, 142-145. [in Ukrainian]

3. Ignatyuk, O. A. (2011). Osoblivosti pidgotovki suchasnix faxivcziv u sistemi vishhoï profesijnoï osviti SShA. Teoriya i praktika upravlinnya soczial'nimi sistemami, 1, 55-64. [in Ukrainian]

4. Ishhenko, O. B. (2009). Vivchennya anglijs'koï movi v umovax vstupu Ukraïni u evropejs'kij osvitnij prostir. Visnik L'vivs'kogo universitetu, 25, 353-357 [in Ukrainian].

5. Nikolaeva, Zh.V. (2004). Navchannya inozemnix mov u VNZ u konteksti Zagal'noevropejs'kix Rekomendaczij z movnoï osviti. Naukovi praczi. Pedagogichni nauki, 29, 127-130/ [in Ukrainian]

6. Polikarpova, Yu. O. (2004). Tradytsii ta innovatsii u vykladanni inozemnykh mov v umovakh intehratsii Ukrainy do svitovoi spilnoty. URL: http://www.academia.edu/2079153/ (accessed 10.08.2021). [in Ukrainian]

7. Rudnytska, T. H. (2008). Innovatsiini metody navchannia inozemnykh mov u vyshchii shkoli v konteksti humanistychnoi spriamovanosti navchalnoho protsesu. Humanizm ta osvita. URL: http://conf.vntu.edu.ua/humed/2008/ttt/Rudnizka.php (accessed 10.08.2021). [in Ukrainian]

8. Common European framework of reference for languages: learning, teaching, assessment. Language Policy Unit, 
Strasbourg. URL: https://www.coe.int/t/dg4/linguistic/Source/Framework_EN.pdf (accessed 10.08.2021).

9. Moodie, G. (2002). Identifying Vocational Education and Training. Journal of Vocational Education and Training. Vol. 54. № 2. P. 266-249.

10. Common European framework of reference for languages: learning, teaching, assessment. Language Policy Unit, Strasbourg. URL: https://www.coe.int/t/dg4/linguistic/Source/Framework_EN.pdf (accessed 10.08.2021).

11. Douglas, H. (2007). Teaching Principles, An Interactive Approach to Language Pedagogy, 569.

12. Harasim, L., Hiltz, S., Tells L., Turoff M. (1995). Learning Networks: a Field Guide to Teaching and Learning on line. MIT Press, Cambridge MA, 145.

13. Humboldt, W. (1985). Language and cultural philosophy. Progress, Moscow, 450. York, 56-78.

14. Henning, J. (2008). The Art of Discussion-Based Teaching: Opening Up Conversation in the Classroom. Routledge, New 197.

15. Hughes, R. (2011) Teaching and Researching: Speaking (Applied Linguistics in Action). Pearson Education Limited.,

16. Littlewood, W. (1991). Communicative Language Teaching. CUP, Cambridge, 34-56. 266-289.

17. Moodie, G. (2002) Identifying Vocational Education and Training. Journal of Vocational Education and Training, 54(2),

18. Vasylyshyna, N. (2014). English in Context. PRINT LINE, Kyiv, 196.

19. Yıldirım, A. (2001). A Qualitative Assessment of the Curriculum Development Process at Secondary Vocational Schools in Turkey. Journal of Career and Technical Education, 1, 57-59.

20. Zagonari, E. (2009). Balancing tourism education and training: International Journal of Hospitality Management. International Journal of Hospitality Management, 28, 2-9.

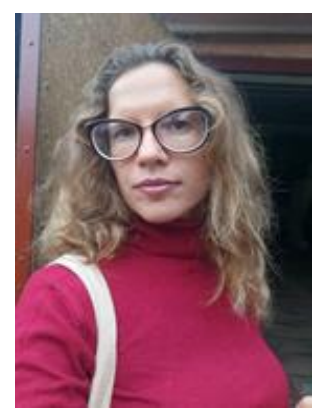

\section{Василишина Наталія Максимівна,}

Д-р.пед.наук, доцент, доцент кафедри іноземних мов,

Факультет міжнародних відносин,

Національний авіаційний університет,

вул. Метрологічна 6, кв.103, Київ, 03143.

Тел. (068)59-30-727. E-mail: filologyN@gmail.com

\section{Vasylyshyna Nataliia Maksymivna,}

D.Sc. in Pedagogics, Associate Professor, Associate Professor of Foreign Language Department

Faculty of International Relations,

National aviation university,

Metrologichna Street 6, flat 103, Kyiv, Ukraine, 03143.

Тел. (068)59-30-727. E-mail: filologyN@gmail.com

ORCID: 0000-0002-0003-9998

Researcher ID: ID: H-1189-2019

\section{Citation (APA):}

Vasylyshyna N. (2021). Modern Regularities and Principles of Foreign Language Education of Future Specialists in International Relations in the Process of Professional Training. Engineering and Educational Technologies, 9 (3), 31-40. doi: https://doi.org/10.30929/2307-9770.2021.09.03.03

\section{Цитування (ДСТУ 8302:2015):}

Василишина Н. М. Сучасні закономірності та принципи іншомовної освіти майбутніх фахівців з міжнародних відносин у процесі фахової підготовки / Інженерні та освітні технології. 2021. Т. 9. № 3. С. 31-40. doi: https://doi.org/10.30929/23079770.2021.09.03.03

Обсяг статmі: сторінок-10; умовних друк. аркушів- 1,448. 